\title{
Correction to: A linear-time branching-time perspective on interface automata
}

\author{
Walter Vogler ${ }^{1} \cdot$ Gerald Lüttgen $^{2}$
}

Published online: 8 July 2021

(c) The Author(s) 2021

\section{Correction to: Acta Informatica (2020) 57:513-550 https://doi.org/10.1007/s00236-020-00369-4}

The article "A linear-time branching-time perspective on interface automata", written by Walter Vogler, Gerald Lüttgen was originally published electronically on the publisher's internet portal (currently SpringerLink) on May 06, 2021 without open access. The copyright of the article changed to (C) The Author (s) and this article is licensed under a Creative Commons Attribution 4.0 International License, which permits use, sharing, adaptation, distribution and reproduction in any medium or format, as long as you give appropriate credit to the original author(s) and the source, provide a link to the Creative Commons licence, and indicate if changes were made. The images or other third party material in this article are included in the article's Creative Commons licence, unless indicated otherwise in a credit line to the material. If material is not included in the article's Creative Commons licence and your intended use is not permitted by statutory regulation or exceeds the permitted use, you will need to obtain permission directly from the copyright holder. To view a copy of this licence, visit http://creativecommons.org/licenses/by/4.0/.

The original article has been updated.

Open Access This article is licensed under a Creative Commons Attribution 4.0 International License, which permits use, sharing, adaptation, distribution and reproduction in any medium or format, as long as you give appropriate credit to the original author(s) and the source, provide a link to the Creative Commons licence, and indicate if changes were made. The images or other third party material in this article are included in the article's Creative Commons licence, unless indicated otherwise in a credit line to the material. If material is not included in the article's Creative Commons licence and your intended use is not permitted by statutory regulation or exceeds the permitted use, you will need to obtain permission directly from the copyright holder. To view a copy of this licence, visit http://creativecommons.org/licenses/by/4.0/.

Publisher's Note Springer Nature remains neutral with regard to jurisdictional claims in published maps and institutional affiliations.

The original article can be found online at https://doi.org/10.1007/s00236-020-00369-4.

Gerald Lüttgen

gerald.luettgen@swt-bamberg.de

Walter Vogler

walter.vogler@informatik.uni-augsburg.de

1 Institute for Computer Science, The University of Augsburg, Augsburg, Germany

2 Software Technologies Research Group, The University of Bamberg, Bamberg, Germany 